\title{
THE SEASONAL CYCLE IN THE CORNISH PILCHARD, SARDINA PILCHARDUS WALBAUM
}

\author{
By C. F. Hickling, M.A. \\ Ministry of Agriculture and Fisheries
}

(Text-figs. I-8)

CONTENTS

\begin{tabular}{|c|c|c|c|c|c|c|c|}
\hline \multicolumn{8}{|c|}{ CONTENTS } \\
\hline Introduction & . & & & ${ }^{\circ}$ & & & II5 \\
\hline \multicolumn{5}{|c|}{ The seasonal variation in mean weight } & & & II 7 \\
\hline \multicolumn{3}{|c|}{ The composition of the flesh } & . & . & & & II 8 \\
\hline \multicolumn{3}{|c|}{ The spawning cycle } & 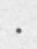 & & & & I25 \\
\hline \multicolumn{3}{|c|}{ The rate of feeding } & . & & & & 128 \\
\hline \multicolumn{3}{|c|}{ The food of the pilchard } & . & - & & & 129 \\
\hline \multicolumn{4}{|c|}{ The seasonal course of growth } & . & & & 132 \\
\hline Discussion & . & . & . & . & & & I34 \\
\hline Summary & . & . & . & . & & & I37 \\
\hline References & . & 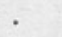 & . & . & & & I37 \\
\hline
\end{tabular}

\section{INTRODUCTION}

From July 1935 to November 1938 research was carried out on the stock of pilchards (Sardina pilchardus Walbaum) which supplies the pilchard fishery of Cornwall.

During these forty-one months some ninety-nine samples were obtained from the Cornish fishing ports, or an average of between two and three samples per month; but the seasonal distribution of sampling was necessarily irregular in consonance with the great seasonal variation in the intensity of the fishery. Most of the samples were obtained in the months from July to October, the height of the fishery.

Some of the work was done at the Plymouth Laboratory, and I will here express my thanks to the late Director, Dr S. Kemp, F.R.S., and his staff for the facilities they provided.

Since the samples were obtained from the commercial fishing fleets, they do not necessarily represent the stock of pilchards in the north-western English Channel, or even in the vicinity of the Cornish coast, but only that part of it which is within reach of the fishing fleets and available for capture by the fishing gears used. The distinction may be important, for there are discrepancies between, for example, the spawning season, as deduced from the state of the gonads in commercially caught pilchards, and as proved by 
the presence of pilchard eggs in the plankton, which shows that the fishing fleets do not sample the whole pilchard stock.

The pilchard of Cornwall has been investigated by Fage (1920), le Danois (1929), le Gall (I930, I937) and Hickling (1938, I939). Le Gall showed that these pilchards consist mainly of fish of $\mathrm{I} 8-26 \mathrm{~cm}$., with an average length of about $23 \mathrm{~cm}$., and of ages $2-8$ or more, but chiefly 5 and 6 . Both these points have been confirmed by Hickling (1939). As to the rate of growth, there is complete agreement among all these writers that growth is rapid in the first three years of life, so that a length of about $19 \mathrm{~cm}$. is attained by the end of the third year of life, but that thereafter growth becomes very slow, a matter of $\mathrm{I} \mathrm{cm}$. or less per annum. Sexual maturity sets in during the third to fifth years of life, so that the reduction in the rate of growth coincides with the onset of maturity. The greatest length found among the 12,000 pilchards handled in the present research was $27.9 \mathrm{~cm}$.

The pilchards of Cornwall, therefore, as they occur in the commercial catches, are large and old members of their species, which have already passed through their period of rapid growth before entering the fishery, and have become slow growers.

In the present research, each sample consisted of about roo fish. Each fish in each sample yielded the following information:

Length from tip of lower jaw to end of the largest caudal fin ray.

Stomach contents, both the average weight of food per fish and the nature of the food.

Intestinal fat. The amount of intestinal fat was noted.

Gonads. The sex of the fish, the state of development of the gonads, and the weight of the gonads.

Weight. The weight of the gutted fish.

From each fish a scale was taken, and these have been used in the present paper in connexion with the growth of the fish and the scale.

On the minced flesh of a few pilchards, prepared as for canning with the head, tail and gut removed, an analysis was made of the fat, water and ash content. About five fish were taken from each of three groups of pilchards, namely, the small fish of less than $20 \mathrm{~cm}$., the medium-sized fish of $20-23 \mathrm{~cm}$., and the large fish of $23 \mathrm{~cm}$. and upwards. In many samples, however, especially in winter and spring, small fish were lacking.

The fat content was estimated, during the first year's work, by digesting the minced flesh with hydrochloric acid, and then extracting the fat from the resulting soup with ether and petroleum ether. For the remainder of the time, however, the much handier Soxhlet method, as modified by Wimpenny (1938), was used, and it was therefore necessary to compare the results obtained by the two methods. For this purpose a number of determinations of the fat content of the same material was made by both methods; the results showed a very high degree of agreement, but the Soxhlet method gave consistently the higher figures for fat content. The correlation coefficient 
between the two series of determinations was +0.93 , and the regression coefficient for the conversion of the bulk-extraction results to the Soxhlet results is given by:

(Percent. fat, Soxhlet $)=I \cdot I$ (percent. fat, bulk ext.) $+I \cdot 4$.

By means of this formula the first year's results were converted so as to be comparable with the later years' results, and they are so presented in this paper. The word 'fat' will here be used to mean 'ether-soluble matter'.

The water content was estimated by prolonged evaporation on a steam bath, followed by drying to a constant weight in an electric oven at $80^{\circ} \mathrm{C}$.

The ash content was estimated by combustion. Unfortunately, in samples containing an abundance of fat, it was often impossible to avoid the ignition of the melted and boiling oil, which was then liable to froth over the sides of the pot. A higher degree of experimental error is therefore to be expected in the estimations of ash, than in those of fat and water.

A residual percentage remains after the estimation of the percentage of water, fat and ash. It is obvious that most of this residue must consist of protein, but a test was made to see whether variations in this residue could be ascribed to variations in the protein. For this purpose, the table published by Lepierre \& Rodriguez (1938) was used. These workers estimated the monthly percentage of fat, water, ash and protein in the Portuguese pilchard, over a period of nearly three years. Their data were extracted so as to compare the monthly variations in protein content with the monthly variations in the 'residue' remaining after summing the percentage of fat, water and ash and subtracting the sum from 100. The average percentage of protein was 19.04, of residue 19.60 , and the coefficient of correlation between the variations in the two was $+0 \cdot 708$, a very significant correlation. There would therefore seem to be justification for regarding the 'residue' as largely protein.

\section{The Seasonal Variation in Mean Weight}

Since for each fish in each sample the length and the gutted weight are known, it is an easy matter to calculate the mean weight of a gutted pilchard at each unit of length in each month during which the samples were collected. In Fig. I the mean monthly weights are shown graphically as they occur in. pilchards of 19,21 and $24 \mathrm{~cm}$., representing respectively the small, medium and large pilchards. To show the remaining centimetre lengths would overcrowd the figure, and would be unnecessary, since they all show a similar seasonal variation.

Fig. I shows that the mean weight of a gutted pilchard of given length may fluctuate very widely. For example, in pilchards of $21 \mathrm{~cm}$. the lowest mean weight was 66 , the highest $88 \mathrm{~g}$. Such a wide variation suggests that in the pilchard, as in the salmon and the herring, the flesh plays a very important part in the seasonal cycle of metabolism. 
Within each year, the average weight tends to show a seasonal fluctuation; it is least in March and April, and then increases to a peak in June, July or August. Later, in the autumn, it decreases again, and then reaches a second and greater peak in November or December. Thereafter there is a rapid decline to the minimum in March or April.

In 1936 , as compared with 1935 and 1937 , the mean weight of the pilchard was low.

These results may be compared with those of Ramalho (1933, 1935) on the same species of pilchard caught off Portugal. He dealt with specimens much smaller than those which appear in the pilchard shoals off Cornwall, but found that in those also the minimum weight occurred towards the end of the winter, in March and April. From this minimum there was an increase to the optimum in October or November (as shown in his paper of 1933) or

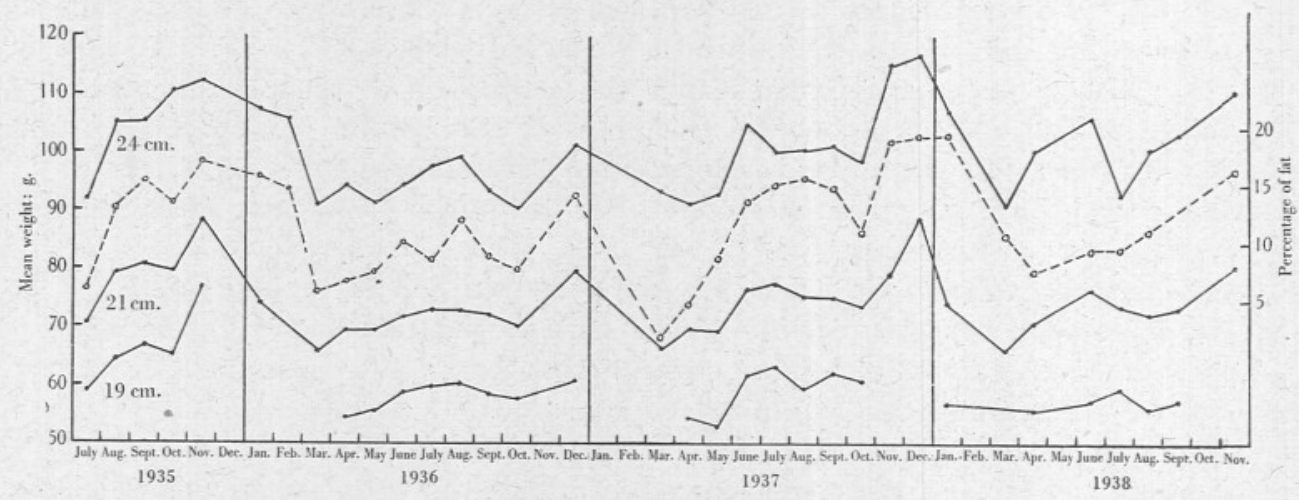

Fig. I. Solid line: monthly mean weight in grams of gutted pilchards of 19,21 and $24 \mathrm{~cm}$. (scale on left). Broken line: monthly mean percentage of fat in pilchards of $20-22 \mathrm{~cm}$. (scale on right).

in the months from June to August (as shown in his paper of 1935). The two stocks of pilchards differ, therefore, in their annual cycle of fluctuations in mean weight, in that those of Portugal appear to reach their maximum mean weight some 2 or 3 months earlier than those of Cornwall, though both have their minimum mean weight at much the same season, and, secondly in that the pilchards of Cornwall have two peaks in their mean weight, in early summer and again in late autumn, whereas those of Portugal show one peak only, in late summer or autumn.

\section{The Composition of the Flesh}

In Fig. I the broken line shows the mean monthly variations in the percentage of fat in the wet weight of pilchards of medium size $(20-22 \mathrm{~cm}$.). The figure shows clearly that the seasonal variations in mean weight described above are very closely associated with the variations in the fat content. The fat eontent tends to be at its lowest in the months of March and April, and then 
to increase to a peak, first, in the summer, in June, July or August, and then to a second and greater peak in November and December. Moreover, just as, in 1936 , the average weight of a pilchard of given length was lower than in the corresponding months of I935, I937 and I938, so also was the fat content lower.

In the table below are shown the correlation coefficients between the variations in the monthly mean weight of pilchards of I9, 2I and $24 \mathrm{~cm}$., and the variations in the monthly mean percentage of fat in pilchards of less than $20 \mathrm{~cm}$., of $20-22 \mathrm{~cm}$., and of $23 \mathrm{~cm}$. and greater.

Correlation between weight of fish and fat content of fish

$\begin{array}{cc}\text { of } & \text { of } \\ 19 \mathrm{~cm} . & <20 \mathrm{~cm} . \\ 2 I \mathrm{~cm} . & 20-22 \mathrm{~cm} . \\ 24 \mathrm{~cm} . & >23 \mathrm{~cm} .\end{array}$

Correlation
coefficient
+0.65
+0.80
+0.89

$\begin{array}{cc}\begin{array}{c}\text { Degrees of } \\ \text { freedom }\end{array} & P \\ \text { I8 } & <0.0 I \\ 30 & <0.0 I \\ 3 I & <0.0 I\end{array}$

The correlation coefficient becomes greater among the larger fish, but, according to the tables of probability in Fisher (I938), all three values are significant, in that a result equally good would be obtained by chance in uncorrelated material less than once in a hundred trials.

These results make it certain that the observed seasonal fluctuations in the mean weight of the fish, shown in Fig. I, are largely due to fluctuations in the fat content. Wagner \& Ramalho (I936) were able to show that in the Portuguese pilchard also there is a close correlation between the condition of the fish, expressed as the relation between weight and length, and the fat content. Moreover, when the results of Ramalho (1933, 1935) on the seasonal variations in mean weight of the pilchard are compared with those of Lepierre \& Rodriguez (1938) on the seasonal variations in fat content, a close relationship is shown between the two.

In a short paper Hickling (1938) has shown the seasonal variations in the percentage of fat, water and ash as they occurred in pilchards of $20-22 \mathrm{~cm}$. The variations in the fat content have already been reproduced in Fig. I of the present paper, and it has just been shown that the percentage of fat is correlated with the changes in mean weight in small, medium and large pilchards.

The water content fluctuates inversely with the fat content. Bruce (I924) showed this very clearly in the herring; in the pilchard the inverse relation is remarkably good. Below are given the correlation coefficients between the mean monthly percentages of fat and water as found in the present series of samples.

Correlation coefficients between fat content and water content of pilchards

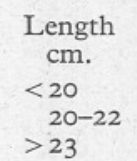

23

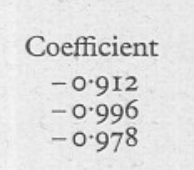

Degrees of freedom $P$

$\begin{array}{ll}\text { II } & <0.0 I \\ 20 & <0.0 I \\ 20 & <0.0 I\end{array}$


There is a very high degree of inverse correlation between the two, indeed, in pilchards of $20-22 \mathrm{~cm}$. it would hardly be possible to expect a higher correlation coefficient in biological material.

The ash content tends to fluctuate directly with the water content and therefore inversely with the fat content. Below are given the correlation coefficients between the monthly mean variations in the fat content and the ash content.

\begin{tabular}{|c|c|c|c|}
\hline $\begin{array}{l}\text { Length } \\
\mathrm{cm} .\end{array}$ & Coefficient & $\begin{array}{l}\text { Degrees of } \\
\text { freedom }\end{array}$ & $P$ \\
\hline $\begin{array}{l}<20 \\
20-22 \\
>23\end{array}$ & $\begin{array}{l}-0.3320 \\
+0.5478 \\
+0.5759\end{array}$ & $\begin{array}{l}\text { II } \\
20 \\
20\end{array}$ & $\begin{array}{l}>0.1 \\
<0.01 \\
<0.01\end{array}$ \\
\hline
\end{tabular}

The values for $P$ show that, in pilchards of $20-22$ and of $23<\mathrm{cm}$., there is a significant positive correlation between the variations in water content and ash content. In small pilchards of less than $20 \mathrm{~cm}$. there is no correlation. But since these small pilchards are usually present in the samples only during the summer months, when the variations in fat and water content are not great, it may be that variations due to experimental error, which, for the reasons given earlier, may be great in the estimation of ash, are of the same order of magnitude. However this may be, in the medium- and large-sized pilchards, for which a more complete series is available, there is a significant positive correlation between the water content and ash content.

The average percentage composition of the pilchard at the time of maximum mean weight in November, December and January was:

$\begin{array}{ccccc}\begin{array}{c}\text { Length } \\ \mathrm{cm} .\end{array} & \text { Fat } & \text { Water } & \text { Ash } & \text { Residue } \\ 20-22 & 17 \cdot 2 & 63.6 & 1.6 & 17 \cdot 6 \\ 23 & 16.0 & 64.5 & 1 \cdot 7 & 17 \cdot 8\end{array}$

At the time of minimum mean weight in March and April the composition was:

$\begin{array}{llccc}\begin{array}{l}\text { Length } \\ \mathrm{cm} .\end{array} & \text { Fat } & \text { Water } & \text { Ash } & \text { Residue } \\ 20-22 & 5 \cdot 8 & 75 \cdot 0 & 1 \cdot 9 & 17 \cdot 2 \\ >23 & 5 \cdot 1 & 75 \cdot 9 & 2 \cdot 0 & 17 \cdot 0\end{array}$

The average composition throughout the whole series of samples, which approximates closely to the average composition at the height of the pilchard fishery is:

$\begin{array}{lcccc}\begin{array}{l}\text { Length } \\ \text { cm. }\end{array} & \text { Fat } & \text { Water } & \text { Ash } & \text { Residue } \\ <20 & 13 \cdot 6 & 66 \cdot 8 & \text { I.6 } & \text { I8.0 } \\ 20-22 & \text { II } \cdot 2 & 68 \cdot 6 & \text { I.7 } & \text { I8.5 } \\ >23 & 9 \cdot 4 & 70 \cdot 2 & \text { I.8 } & 18 \cdot 6\end{array}$

These figures show that during the height of the pilchard fishery, when almost the whole of the year's catch is landed, the smaller pilchards are more valuable than the large ones from the nutritional point of view. 
To sum up, therefore, in this series of samples of pilchards, the water and ash content varied inversely with the fat content, and therefore inversely with the mean weight of the fish.

If an increase in the weight of the fish is accompanied by a decrease in the percentage of water present, it follows that the actual weight of water present in a fish of given length must remain more or less stationary. In the present

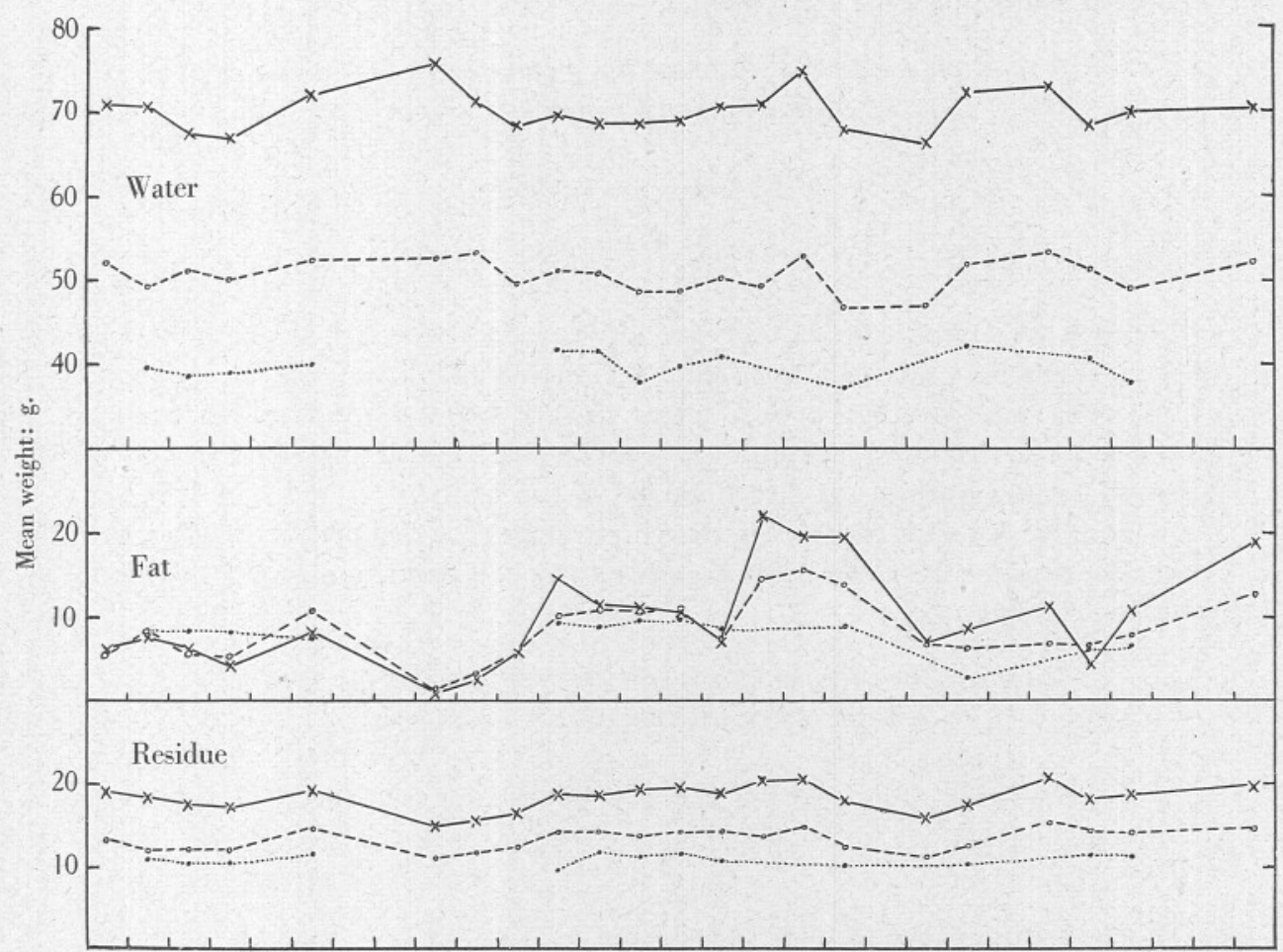

July Aug. Sept. Oct. Nov. Dec. Jan. Feb. Mar. Apr. May June July Aug. Sept. Oct. Nov. Dec. Jan. Feb. Mar. Apr. May June July Aug. Sept. Oct: Nov, 1936 1937

1938

Fig. 2. Calculated monthly mean weight of water, fat and 'residue' in pilchards of three length groups.

$$
\text { ...... } 19 \mathrm{~cm} \text {. }-24 \mathrm{~cm} \text {. }
$$

experiments, both the mean weight of the fish and the percentage of fat, water and ash are known, and it is therefore a simple calculation to find, in a fish of given weight, what is the actual weight of water, fat and ash present, and also, by subtraction, what is the weight of the 'residue' which, of course, is chiefly protein.

In Fig. 2, pilchards of $19 \mathrm{~cm}$. are taken to represent the fish of less than $20 \mathrm{~cm}$., pilchards of $21 \mathrm{~cm}$. those of $20-22 \mathrm{~cm}$., and pilchards of $24 \mathrm{~cm}$. to represent those greater than $23 \mathrm{~cm}$. Fig. 2, therefore, represents the seasonal 
variations in the calculated weight of fat, water, ash and protein present in pilchards of I9, 2I and $24 \mathrm{~cm}$. respectively.

Fig. 2 shows that the amount of water present varies from sample to sample, but there is no regular seasonal variation, and there is no correlation between the weight of water present and the total weight of the fish. In the table below, the correlation coefficients between the weight of the fish and the weight of water present, are shown.

Correlation coefficients between the mean weight of the fish and the calculated weight of water present

$\begin{array}{cccc}\begin{array}{c}\text { Length } \\ \mathrm{cm} .\end{array} & \text { Coefficient } & \begin{array}{c}\text { Degrees of } \\ \text { freedom }\end{array} & P \\ \text { I9 } & +0.4423 & \text { II } & >0 . I \\ 2 \text { I } & +0.3248 & 2 \text { I } & >0 . I \\ 24 & +0.3694 & 2 \text { I } & 0 . I\end{array}$

There is no significant correlation between the two, for an equally good relation could be obtained by chance in uncorrelated material at least once in ten trials, and therefore it can be concluded that the observed fluctuations in the amount of water present are due to chance and play no part in the seasonal fluctuations in the mean weight of the fish.

On the other hand, there is a very high degree of correlation between the seasonal fluctuations in the mean weight of the fish and those in the calculated weight of fat present.

Correlation coefficients between the mean weight of the fish and the calculated weight of fat present

$\begin{array}{cccc}\begin{array}{c}\text { Length } \\ \text { cm. }\end{array} & \text { Coefficient } & \begin{array}{c}\text { Degrees of } \\ \text { freedom }\end{array} & P \\ \text { I9 } & +0.8298 & 18 & <0.0 I \\ 2 \text { I } & +0.8609 & 30 & <0.0 I \\ 24 & +0.9150 & 3 I & <0.0 I\end{array}$

The correlations are all very significant.

The fluctuations in mean weight of the entire fish are due therefore largely to fluctuations in the fat content and not to fluctuations in the water content. The ash content may be neglected, as it is too small to have much effect on the total weight of the fish.

But Fig. 2 also shows that the amount of 'residue', that is, mainly protein, shows a small seasonal variation, and that, among the larger fish at least, it is positively correlated with the fat variations.

Correlation coefficients between the seasonal fluctuations in the calculated weight of fat and of protein present

$\begin{array}{cccc}\begin{array}{c}\text { Length } \\ \mathrm{cm} .\end{array} & \begin{array}{c}\text { Correlation } \\ \text { coefficient }\end{array} & \begin{array}{c}\text { Degrees of } \\ \text { freedom }\end{array} & P \\ \text { I9 } & +0.094 & \text { II } & >0 . I \\ \text { II } & +0.57 \text { I } & 20 & <0.0 \text { I } \\ 24 & +0.663 & 20 & <0.0 \text { I }\end{array}$


In the fish of $19 \mathrm{~cm}$. there is no correlation between the seasonal variations in fat content and the variations in the quantity of 'residue', but there is a significant correlation in the case of the fish of $2 \mathrm{I}$ and $24 \mathrm{~cm}$. This suggests that the small pilchards do not draw upon the reserves contained in the 'residue', but the larger fish do, and since the value of the correlation coefficient is greater in pilchards of $24 \mathrm{~cm}$. than in those of $2 \mathrm{I} \mathrm{cm}$., the amount to which the 'residue' is drawn upon at the times when fat is also drawn upon is greater in the larger fish than in those of intermediate size.

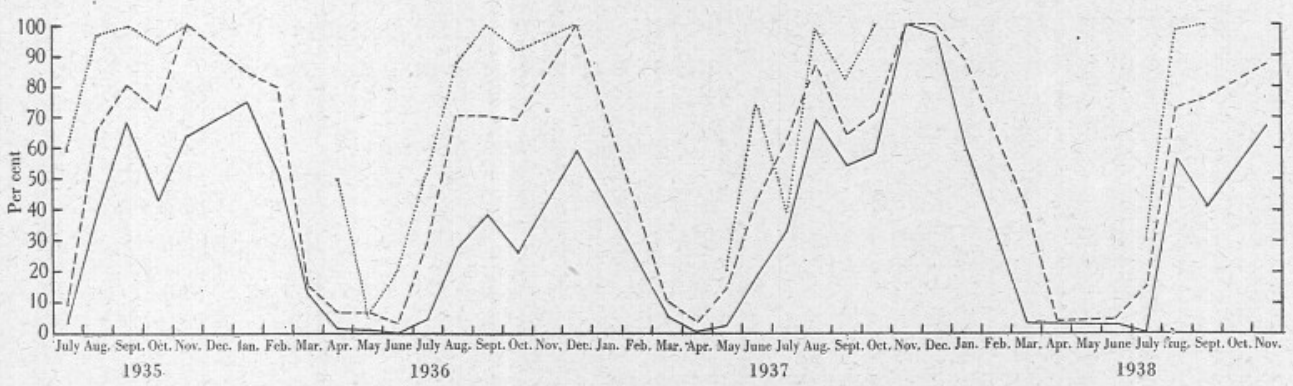

Fig. 3. Monthly mean percentage of pilchards of three length groups with abundant intestinal fat.

$\ldots \ldots<20 \mathrm{~cm}$. $--20-22 \mathrm{~cm}$. $\longrightarrow 23 \mathrm{~cm}$.

So far the fat contained in the flesh has been dealt with, that is, fat present beneath the skin and between the muscles. But abundant fat is also stored in the mesentery. Fig. 3 shows the seasonal variations in the percentage of fish having abundant fat in the mesentery. In spite of the very arbitrary classification of the fish into 'fat' and 'not fat', the percentage of 'fat' fish shows a well-marked seasonal variation almost identical with that for the percentage of fat present in the flesh.

Correlation coefficients between the seasonal variations in the intestinal fat and the percentage of fat in the flesh

$\begin{array}{cccc}\begin{array}{c}\text { Length } \\ \text { cm. }\end{array} & \text { Coefficient } & \begin{array}{c}\text { Degrees of } \\ \text { freedom }\end{array} & P \\ <20 & +0.4804 & \text { I } & 0.02-0.05 \\ 20-22 & +0.8526 & 30 & <0.01 \\ >23 & +0.7094 & 31 & <0.01\end{array}$

The correlations are significant in pilchards of large and of medium size, but doubtfully so in small pilchards, since an agreement as good as that found could be obtained by chance in uncorrelated material between twice and five times in a hundred trials. But the correlation is a general one only; in the spring the body fat begins to regenerate before the intestinal fat, and in the autumn the intestinal fat is drawn upon to a greater extent than the body fat. 
A series of four analyses showed that one gram of body fat is equivalent to $0.133 \mathrm{~g}$. of intestinal fat in the seasonal variations of the fat content of the fish.

One other organ which, in many species of fish, is the main storage organ for fat, namely, the liver, remains to be considered. Lovern \& Wood (I937) say of the liver of the herring that it is a small organ of little or no significance as a depot for fat. The same is true of the liver of the pilchard. It usually weighs between I and $2 \mathrm{~g}$. only, and the two following analyses, made respectively in April, when the fat content of the fish as a whole is at its lowest, and in November, when the fat content of the fish as a whole is at its highest, show the percentage of fat, water, ash and residue present.

\section{Composition of the liver of the pilchard}

$\begin{array}{lcccc} & \text { Fat } & \text { Water } & \text { Ash } & \text { Residue } \\ \text { April } & 3.61 \% & 72 \cdot 30 \% & 1.83 \% & 22 \cdot 26 \% \\ \text { November } & 7.50 \% & 70.84 \% & 1.75 \% & 19.91 \%\end{array}$

Clearly, the liver never contains much fat, and since the entire liver only weighs a gramme or two any fat stored in such small quantities in such a small organ may be neglected.

It would therefore appear that, as this section shows, the seasonal variations in the mean weight of a fish of given length described on p. II8 are due to the seasonal variations in the fat content, and, among the larger fish, to a slight extent to the seasonal variation in the content of 'residue'. The water content plays no part in the seasonal variation in mean weight of the fish, nor does the ash. The various constituents of the flesh of the pilchard may be likened to two, water and ash, which form a constant framework; one, fat, which is stored up in, and withdrawn from, this framework, the variations in fat causing the variations in mean weight; and finally, 'residue', no doubt mainly protein, which should probably be regarded as part of the permanent framework, but which can also be drawn upon to some extent. Besides the fat in the flesh, the intestinal fat is stored and replenished in the same way and should be added to the former.

Fig. 2 also shows that though the quantity of water increases rapidly with increase of length, the quantity of fat is approximately the same for fish of 19,21 and $24 \mathrm{~cm}$.

Actually there is a very slight increase in the calculated average weight of fat present, namely, from $7.8 \mathrm{~g}$. in fish of $19 \mathrm{~cm}$. to $8.4 \mathrm{~g}$. at $24 \mathrm{~cm}$. But when the data are tested statistically by the analysis of variance, the difference cannot be considered significant. This means that in relation to the weight of the fish, which continues to increase with increase of length, the quantity of fat must diminish. 


\section{The Spawning Cycle}

In examining the factors which may account for the withdrawal of fat from the tissues of the fish, and its restoration, the easiest to attack is the spawning cycle, which accounts directly for the loss of a large amount of material, which must later be replaced.

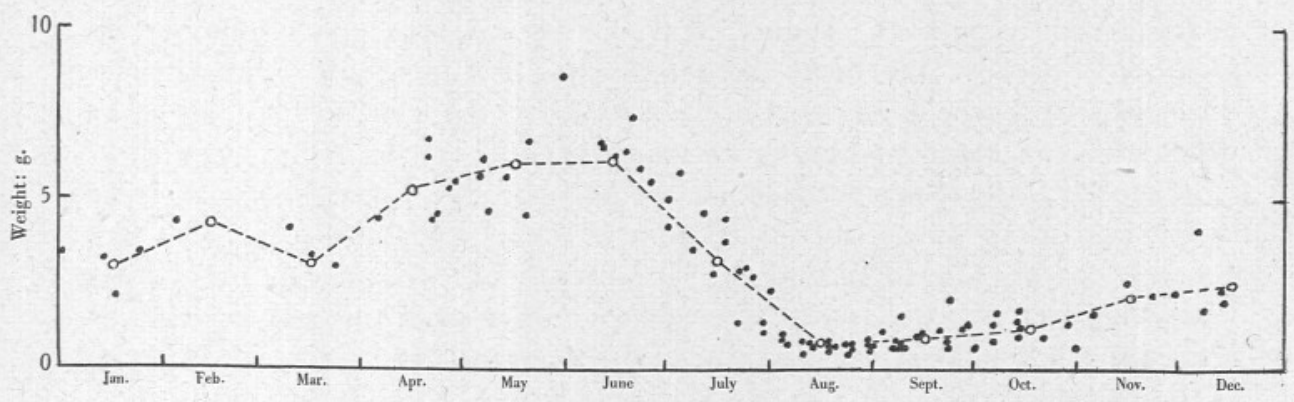

Fig. 4. Average weight of testis in each sample with (indicated by circles) calculated monthly averages.

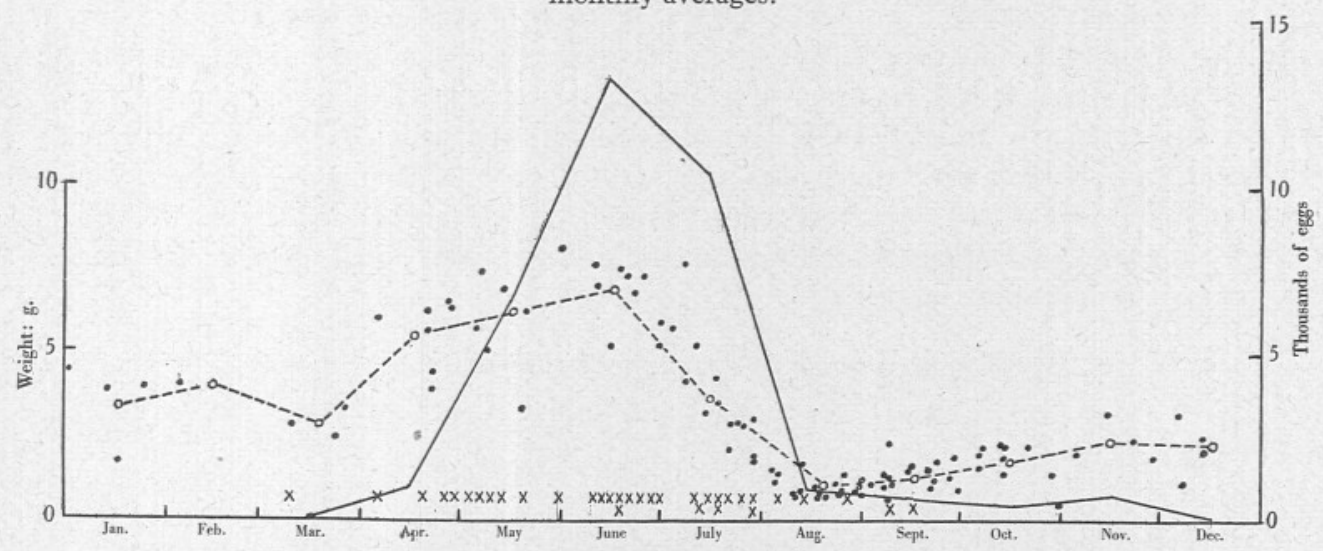

Fig. 5. Spawning of pilchards: females. Average weight of ovary in each sample, with monthly mean weights (scale on left), and average number of pilchard eggs taken per haul off Plymouth (scale on right).

- average weight of ovary. $\quad \times$ spawning fish.

calculated monthly average. $\quad-$ monthly average number of pilchard eggs off Plymouth.

In Figs. 4 and 5 the average weights of the gonads of male and female pilchards, respectively, in each sample are plotted against the date of collection. Unlike the data as to mean weight and chemical composition, which differed from one year to another and so necessitated the setting out of the data by years, the course of the spawning cycle was practically identical in all the years covered by this research, and so it is possible to plot all the data as if they had been collected in a single year.

The broken line joins the monthly means. 
It should here be said that, with very rare exceptions, all the pilchards dealt with have been mature fish. However, a few sterile fish have been found, in which the gonads have degenerated or have even disappeared entirely. In the latter case the fish may be 'capons', and enormously fat.

Figs. 4 and 5 show that the sexual cycle, as shown by the changes in mean weight of the gonads, is identical in males and females. Both have their lowest mean weight in August, and recovery begins in September and October. The very low mean weights found in August and September are due, not only to the exhaustion of the gonads of the mature fish, but to the very small gonads of pilchards which are about to mature for the first time.

From the time of minimum mean weight in August there is a very steady increase in mean weight to a maximum in June. Then follows a very rapid decrease to the August minimum. The month of July, in each of the four years, has seen this collapse of the gonads, for in each the gonads have had a high mean weight at the beginning of the month, and a low mean weight at the end of it.

The increase in weight of the gonads in preparation for spawning is accompanied by well-known changes in their naked-eye appearance. The shrivelled and semi-translucent spent testis loses its translucency and gradually becomes opaque and creamy white, until, at a certain indefinite point, a cut across such a testis will show the presence of ripe milt. Testes in this ripe condition have been found over the greater part of the year, as the table below shows. They occurred from January to September inclusive, though the highest percentages were found in the months from April to July. In June almost every testis was ripe.

Average percentage of spawning pilchards in each month

$\begin{array}{cccccccccccc}\text { Jan. } & \text { Feb. } & \text { Mar. } & \text { Apr. } & \text { May } & \text { June } & \text { July } & \text { Aug. } & \text { Sept. } & \text { Oct. } & \text { Nov. } & \text { Dec. } \\ 3 & 7 & \text { I6 } & 53 & 86 & 97 & 54 & 6 & \text { I } & 0 & \text { I } & 0 \\ 0 & 0 & \text { I } & \text { I6 } & 4 & \text { I6 } & \text { I0 } & 0.5 & 0.4 & 0 & 0 & 0\end{array}$

In the female the shrunken and translucent spent ovaries become opaque, and the ripening eggs begin to appear as minute white specks. The ovary continues to increase in size as these eggs enlarge, until the latter become pressed together and impart to the whole ovary a brilliant pinkish white colour. This is the penultimate stage of ripeness, and has been reached by a process as gradual and indefinite as the ripening of the testis.

But the final stage in the ripening of the ovarian eggs is quite definite. Some of the yolky eggs suddenly increase greatly in size and become translucent; they cause the whole ovary to become swollen, and ripe eggs will run from the vent at the slightest pressure. The change, as Milroy showed in 1898 , is due to the absorption of water by the yolky eggs. 'The increase in volume is mainly due to the water, the total solids present in the immature and mature ova being practically the same.' This may also be illustrated in my pilchard material. Below are given the percentage of fat, water, ash and 
residue in ovaries in the penultimate stage of ripeness, and in the actually ripe condition.

$\begin{array}{lcccc} & \text { Fat } & \text { Water } & \text { Ash } & \text { Residue } \\ \text { Penultimate stage of maturation } & \mathrm{I} \cdot 72 \% & 75 \cdot 89 \% & -\mathrm{I} \cdot 70 \% & 20 \cdot 69 \% \\ \text { Ripe condition } & \mathrm{I} \cdot 2 \mathrm{I} \% & 83 \cdot 8 \mathrm{I} \% & \mathrm{I} \cdot 20 \% & \mathrm{I} 3 \cdot \mathbf{7} \% \%\end{array}$

The water content is much higher in the ripe ovaries, and the values for fat, ash and residue are correspondingly depressed. But if the composition of the dry material is compared, it is seen that the final process of ripening has involved no great change in the composition of the 'solids'.

$\begin{array}{lrrr} & \text { Fat } & \text { Ash } & \text { Residue } \\ \text { Penultimate stage of maturation } & 7 \cdot 1 \% & 7 \cdot 0 \% & 85 \cdot 9 \% \\ \text { Ripe condition } & 7 \cdot 4 \% & 7 \cdot 4 \% & 85.2 \%\end{array}$

There is good reason to believe, that, from the rarity with which this final or spawning stage is found in teleosts, it is usually sudden and short-lived; the fish quickly sheds the ripe eggs and the ovary then returns either to the spent condition, or, if spawning is repeated, to a condition indistinguishable from the former penultimate stage of ripeness. In the Californian pilchard Sardina caerulea, for example, Clark (1934) found only four pilchards in this condition in eleven years' study. In the table on p. I26 it will be seen that the mean monthly percentage of female pilchards in this final stage of ripeness was never greater than about $16 \%$.

The table on p. I 26 shows that female pilchards in the final, or actually spawning, condition occurred from March to September, and most frequently in the months from April to July. These are consequently to be regarded as the spawning months, and principal spawning months, respectively, of the Cornish pilchard as deduced from the present material. No significance is to be attached to the lower value found in May.

The same table further shows that the male pilchards are ripe for spawning over a longer period than the females; this appears to be almost universal among fishes.

Russell $(1938,1939)$ gives data as to the number of pilchard eggs occurring in the plankton off Plymouth in 1937 and 1938; in Fig. 5 a curve is drawn showing the average number of pilchard eggs per month per standard haul in the two years. The first eggs were taken in April; they were most abundant in June and July, and became scarce in August, though small numbers continued to occur until December.

The estimate of the principal spawning season, as deduced from the average weight of the gonads and the presence of spawning females, is in excellent agreement with the spawning season as proved by the presence of the eggs in the plankton; but the continued presence in the plankton of small numbers of pilchard eggs throughout October and November cannot be accounted for in the present material. It may be that a little belated spawning takes place far out to sea beyond the normal range of the fishing fleets, and this is con- 
firmed by Cunningham (1893), who mentioned that spawning takes place late in the season in September, Io miles south of the Eddystone, much farther out than the pilchard fleets normally work.

\section{The RATE of FeEding}

The contents of the stomachs of about fifty pilchards from each sample were squeezed out on to a filter paper and weighed. This weight, divided by the number of stomachs taken, gave the average weight of food per stomach. In Fig. 6 the average values are plotted against the date of collection, all years' results being put on to the same graph since, as I have shown elsewhere (1938), the feeding cycle is repeated with the greatest regularity each year. The calculated monthly averages are also shown, and are joined by the broken line.

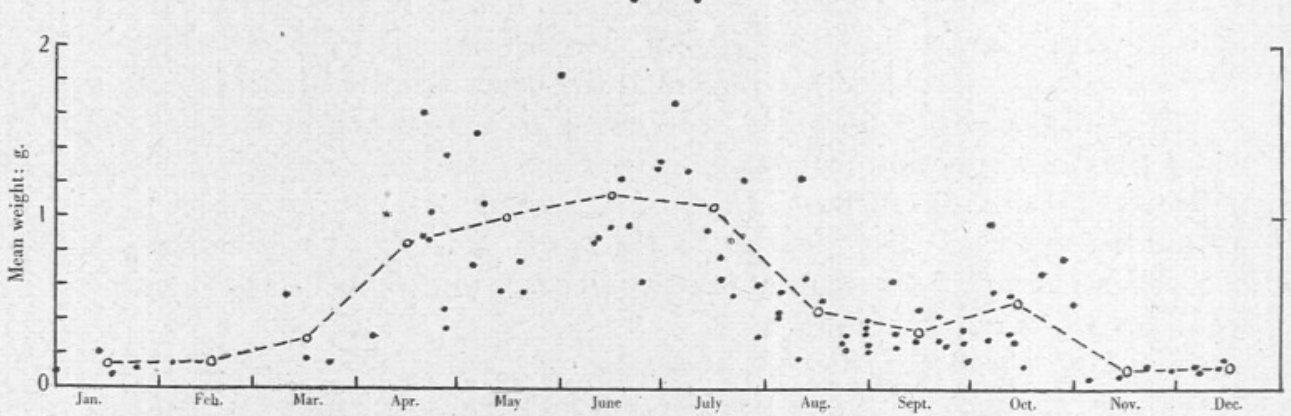

Fig. 6. Average weight of food per stomach in each sample, with monthly mean weights. Dots: average per sample of fifty stomachs I935-8. Circles: calculated monthly averages.

The samples collected in November, December, January and February contained very little food, a nominal quantity of less than O.I g. per fish. In March, however, one sample contained an average of $0.27 \mathrm{~g}$. per fish, and from April to October most of the samples gave evidence of active feeding. The heaviest individual average values were found in June and July, and in May, June and July every sample contained abundant food. In the latter part of August and in September the samples contained much less food, but in October there was a recurrence of samples containing more plentiful food.

The calculated monthly averages reflect these conclusions drawn from the individual samples; they show an increase in the average weight of food per stomach from February to a maximum in June. In July and August and September there is a decline, but a secondary increase occurs in October.

Clearly, the months of May, June and July are the principal months during which the pilchard feeds, with a secondary recovery in October, just before the winter fast sets in.

As far as I know, there have been no previous estimates of the seasonal rate of feeding in the pilchard. It is interesting to note, however, that in the herring, Savage (1935) found a very similar course of events. In that fish, 
however, the time of heaviest feeding was in May, with a secondary recovery in September. Fig. 6 shows that appreciable quantities of food are still being taken during August and September, which are the principal months of the commercial pilchard fishery. As this food is planktonic, the gut contents quickly liquefy, and for this reason pilchards cannot be despatched for long distances by rail. But if the gut is removed, this fish will travel as well as other species.

\section{The Food of The PILChard}

A very rough analysis was made of the nature of the food of the pilchard throughout the year. The stomach contents of about fifty fish, after weighing, were shaken up in a jar of water and a few drops were withdrawn with a pipette and examined on a glass slide. One hundred 'unselected' organisms were classified under the six general headings, which were found to include all the most important and consistently recurring organisms:

(I) Copepods, including the adults and later developmental stages.

(2) Other Crustacea, including, beside adult ostracods, euphausiids, mysids and amphipods, the young and larval stages of many groups of Crustacea, including the earlier stages of copepods.

(3) Diatoms.

(4) Peridinians.

(5) Molluscs. Chiefly the larvae of lamellibranchs and gastropods, but also including, especially in June 1937 , Limacina.

(6) Eggs. Including mainly the eggs of copepods, some of which, of course, may have been detached from the females after ingestion by the fish.

The results of the analysis are shown in Fig. 7. The percentages of organisms assigned to each of the six groups have been raised by the average weight of food per stomach in that sample, and all samples have been combined as monthly means. The reason for this treatment of the data is that the importance of each group of food organism is brought into relation with the general feeding cycle. The disadvantage of the method is that it does not, at the same time, indicate the relative importance of each group of organisms as food for the fish. One large crustacean larva or mysid may be equivalent in weight to several copepods, and one copepod to a great many diatoms or peridinians. Fig. 7 , in fact, only shows which groups of organisms are of the greatest numerical importance in the different phases of the seasonal feeding cycle of the fish.

Besides the organisms grouped under the six main heads enumerated above, many others made occasional appearances; for example, tintinnids were frequent in one or two samples, while Oikopleura, Sagitta and very small fish were seen from time to time. But here attention will be confined to the six most important and constantly recurring groups.

The food of the Cornish pilchard is exclusively planktonic. It includes some very small forms, such as the diatom Prorocentrum micans, which was very abundant in some samples. But the gill rakers of the pilchard end in tufts of very fine processes (well figured by Schofield (I934) for the closely 
allied Californian pilchard, Sardina caerulea) and form a filtering apparatus much finer than that of the sprat, mackerel or even very small herrings, as I have found by examining these fish.

No analysis was attempted of the very small quantities of food present in the stomachs in winter. Much of it was unrecognizable, and may have been secretions from the walls of oesophagus and stomach, but the recognizable organisms included amphipods, a few diatoms and the nauplii of cirripedes.

Referring to Fig. 7, it will be seen that copepods were, numerically, one of the most important items in the food of the pilchard, and, when regard is had to their comparatively large size, they were in fact the most important. They reached their greatest importance numerically in May, June and July,

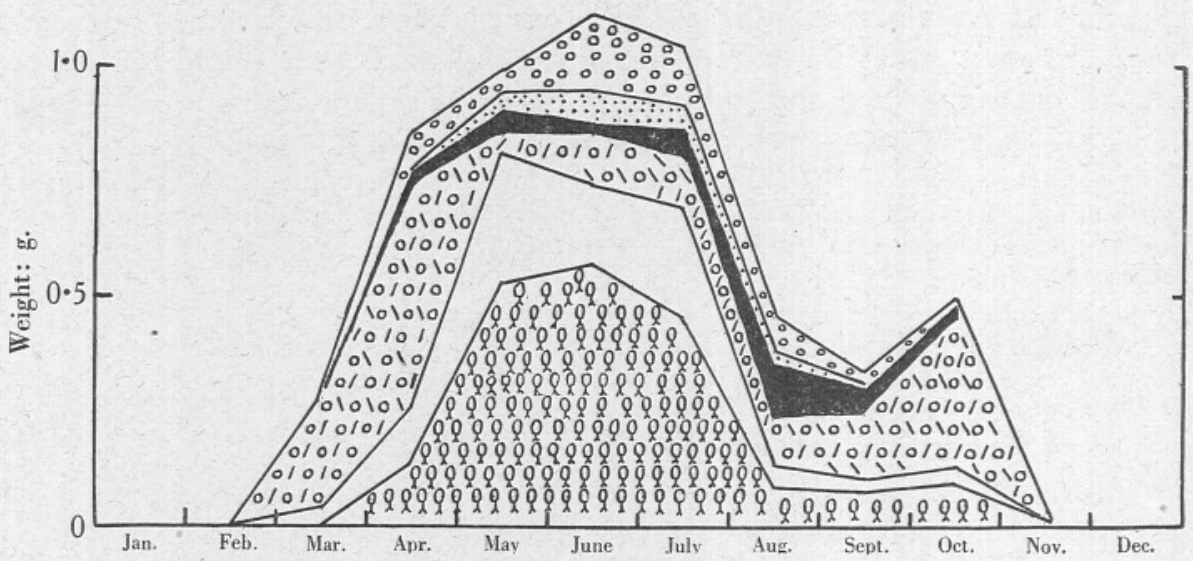

Fig. 7. Principal constituents of food of pilchard, calculated as monthly averages 1935-8. Q 20 copepods.
o|lolo diatoms. peridinians.
$\because: 0$ molluscs.
0 eggs.

at the time when the feeding of the pilchard was at its heaviest. Crustacea reached their maximum importance in May, but were an important item of food throughout the summer.

Diatoms showed two periods of greatest numerical importance. The first period was in the spring, and especially in April; the second in the autumn, and especially in October. The colour of the stomach contents of the pilchard in October was frequently green, and one or two of the samples were almost pure diatom. The food of the pilchard therefore closely reflects the wellknown double nature of the annual diatom crop; indeed, the secondary recovery in the rate of feeding of the pilchard, in October, is almost wholly due to this autumn crop of diatoms. Lewis (1929) found that diatoms form a very important item in the food of the Californian pilchard also. Hart \& Wailes (1932) found that this species feeds mainly on diatoms and crustacea, and only slightly on Oikopleura. 
Peridinians had their greatest numerical importance in August and September, molluscs in May, June and July, and finally, eggs, chiefly copepod eggs, were most plentiful in June and July, a consequence, probably, of the maximum abundance of adult copepods, as shown by the stomach contents, in May and June.

Fage (1920) briefly summarized the previous work on the food of the pilchard. Cepède and Mangin both found young pilchards in the Channel and the Bay of Biscay feeding heavily on diatoms in September, though the larger specimens were not so exclusively feeding on them. Pouchet \& le Guerre found adult pilchards with their stomachs containing an extraordinary number of peridinians, about 20 millions of Peridinium polyedricum Pouchet per specimen, apparently.

More recently Desbrosses (1933) has shown that, in the northern part of the Bay of Biscay, the food of the sardine or small pilchard consists, in July and August, of crustacea and especially copepods, though he also records gastropod larvae in July. But in September, October and November phytoplankton was predominant in the food, especially diatoms, and crustacea were very rare. These results are similar to those described above for the Cornish pilchard.

The food of the Cornish pilchard has been very carefully studied by Swithinbank \& Bullen (1913). The summer pilchards, in Mount's Bay and Mevagissey Bay, were feeding mainly on copepods, chiefly Pseudocalanus and Temora, but in August, I913, abundant phytoplankton was present in the stomachs. In October, phytoplankton was abundant in samples from Mevagissey Bay, with plentiful Oikopleura also, but in Mount's Bay Oikopleura was not detected, and the stomachs contained copepods, chiefly Calanus, and the mollusc Limacina. In January, a few fish larvae and eggs were found.

Comparing the stomach contents of the pilchard with plankton catches made at the same localities, Swithinbank \& Bullen reached the conclusion that the pilchard is a selective feeder, for there were notable discrepancies between the organisms actually found in the stomachs of the pilchards and those taken by plankton nets in the vicinity. It would appear that, where both are available, the zooplankton is preferred to the phytoplankton, and this may even, according to the authors, affect the movements of the pilchard so that an abundance of phytoplankton on the usual fishing grounds may delay the arrival of the pilchards, as in August 1913.

The feeding cycle shown in Figs. 6 and 7 does indeed suggest that there is a considerable difference between the abundance of plankton and the amount of food in the stomach of the pilchard. For example, the average quantity of zooplankton taken appears to decline heavily after June, this decline being responsible for that of the average quantity of food as a whole, whereas there is no evidence that there is such a decline in the abundance of the zooplankton itself. On the contrary, at the nearby 'Seven Stones' lightship, according to Gough (1907) and Bygrave (I9II) copepods, at least, 
remain abundant until November, and, more recently, Harvey, Cooper, Lebour \& Russell (1935) show that, at a position 5 miles south of the breakwater at Plymouth, there is no decline in the abundance of zooplankton after June, but rather a continued increase to a maximum in August and September.

But after the month of June the pilchard shoals usually reach their maximum abundance and density in the coastal waters of Cornwall where the main fishery is carried on. Below are given, for the period covered by the present investigations, the average catch of pilchards per month per boat landing:

$\begin{array}{ccccccccccccc} & \text { Jan. } & \text { Feb. } & \text { Mar. } & \text { Apr. } & \text { May } & \text { June } & \text { July } & \text { Aug. } & \text { Sept. } & \text { Oct. } & \text { Nov. } & \text { Dec. } \\ \text { Cwt. } & 7.6 & 1.8 & 9.2 & 7.7 & 6.9 & 9.8 & 7.7 & 19.5 & 20.5 & 13.2 & 6.5 & 5.0\end{array}$

In the months of August and September, and to a less extent, October, the average weight of pilchards per boat is much higher than at any other time of the year, clearly implying a much greater abundance of pilchards in these months than at other times. The available plankton must then be shared out among a much greater number of fish, resulting in a lowered average quantity for each.

The result, however, for the pilchards must be the same as an actual diminution in the abundance of plankton, namely, a lower average quantity of food available.

Wimpenny (1938) shows that there is a seasonal fluctuation in the fat (ether-soluble matter) in the plankton collected throughout the year at a series of stations off Flamborough Head. The lowest fat content was in February and April, and the maximum is reached in July. From July to September there was a decline in the fat content of the plankton, followed by a secondary increase in November and December. 'Biologically, these two maxima may be related to the spring and autumn outbursts of diatoms which are predecessors of fat storage by the zooplankton.'

In 1938 a few analyses were made of the fat content of the fresh food in the stomach of the pilchard. The results are given below as the percentage of fat in the dry weight of the food:

$$
\begin{array}{cccccccc}
20 \text { Apr. } & 20 \text { June } & 4 \text { July } & \text { II July } & \text { I8 July } & \text { I7 Aug. } & 30 \text { Aug. } & \text { I5 Sept. } \\
16.5 \% & 20.9 \% & 18.5 \% & 16.3 \% & \text { II. } 9 \% & \text { I2.7\% } & 9.4 \% & \text { I } 8.1 \%
\end{array}
$$

There was an increase in the fat content of the food from April to June, and then a steady decline through July to August, followed by an increase in September. It would appear, therefore, that, from June to September, not only is the quantity of food available to each pilchard decreasing, but that the food itself is becoming poorer in fat.

\section{The Seasonal Course of Growth}

The scales of a fish have the function of covering the body, and since the number of scales does not increase, it follows that the existing scales must grow in proportion to the growth of that part of the body which they cover. 
Where, therefore, there is evidence that the scale is growing, which it does by accretion at the margin, it can be assumed that the fish also is growing.

The upper surface of the scale, where this lies within the scale-pocket, is covered with fine striations, but these striations are interrupted or bent at the so-called winter rings, which run parallel to the margin of the scale. These rings provide fixed points by which an estimate can be made as to whether new material was being laid down at the margin of the scale at the time of collection.

For example, a large proportion of the scales collected in April and May show a winter ring just within the margin, with the first beginning of the resumption of the striated structure outside it, and it is reasonable to conclude that, in these samples, growth has just recommenced. From these months onward throughout the summer, the striations extend to the margin of the scale, but in the autumn and winter most of the scales have a structure' at the margin which suggests that the winter ring is being formed there.

In the table below the average monthly percentages of scales examined which were estimated to have the winter ring at the margin are given. Only the scales of the smaller specimens were used, for in the scales of the larger specimens the winter rings become crowded near the margin and it becomes impossible to estimate the nature of the margin.

\section{Percentage of scales with the winter ring at the margin}

$\begin{array}{lrlllll}\text { Jan. } & 86 & \text { Apr. } & 75 & \text { July } & \text { 18 } & \text { Oct. } 82 \\ \text { Feb. } & \text { I00 } & \text { May } & 45 & \text { Aug. } 28 & \text { Nov. } & 73 \\ \text { Mar. } 79 & \text { June } & \text { I0 } & \text { Sept. } & 30 & \text { Dec. } & 92\end{array}$

Only in February (for which month, however, only two suitable scales are available) were the margins all of one type. In all other months both types of margins were found. But this lack of sharpness in the predominance of one type or the other is probably due to the difficulty of assessment already referred to.

The table shows that the scales have the winter ring at the margin from October to March, and to have the intermediate zone of striations at the margin from April to September. It follows that the scale grows from April to September, and this is confirmed by the finding of new striated growth at the margin of the scale, just outside the winter ring, in April and May.

Therefore the fish also probably grows in the months from April to September inclusive, but ceases to grow from October to March.

It also follows that only one winter ring is laid down each year, at least in the majority of the scales, so that a count of the winter rings allows of an estimate of the age of the fish in the pilchard, as in so many other species of fish. 


\section{DisCUSSION}

It has been shown (p. I29) that the pilchard is exclusively a planktonic feeder and indeed has a feeding mechanism which enables it to feed on very small planktonic organisms. But the production of plankton in the sea is a strongly seasonal phenomenon and, therefore, the rate of feeding in the pilchard must always be strongly seasonal, as has been shown in Fig. 6 . The whole metabolism of the fish must be adapted to the seasonal nature of its intake of material.

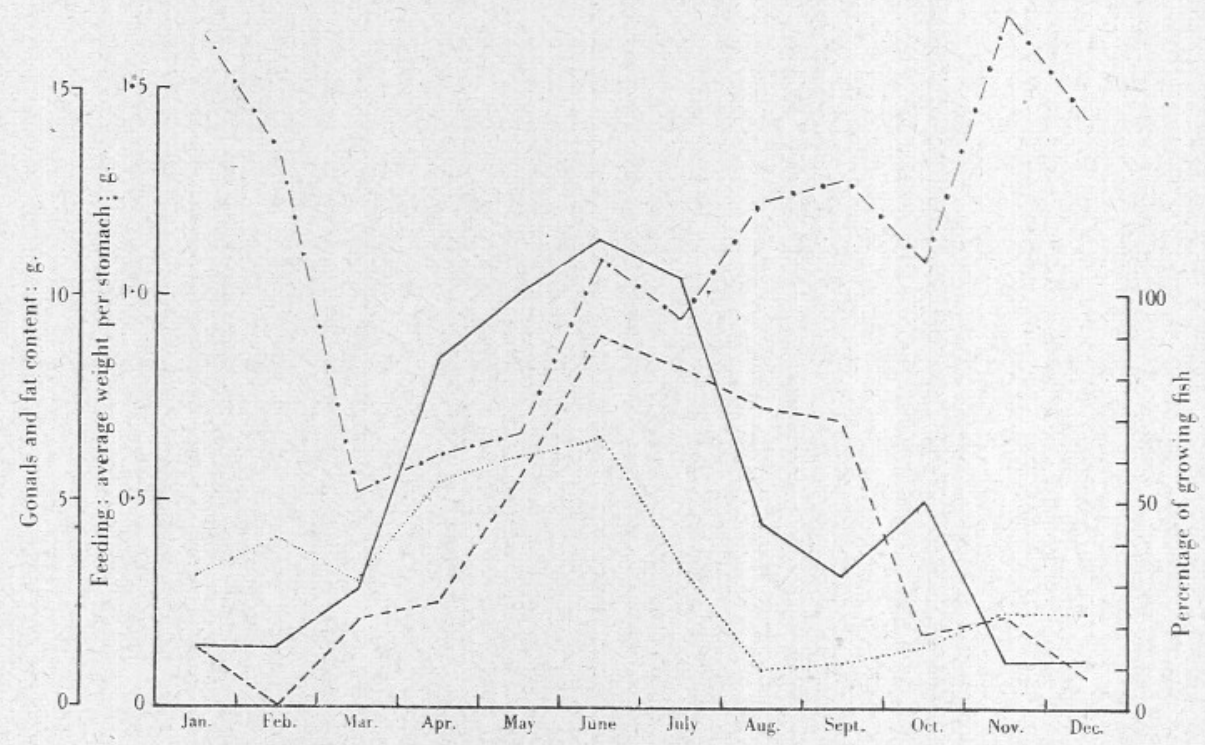

Fig. 8. The seasonal cycles of breeding, feeding, fat storage (scales on left), and percentage of growing fish (scale on right).

$$
\begin{array}{ll} 
& \text { feeding. } \\
\ldots \ldots \text { breeding. } & ---- \text { growth. }
\end{array}
$$

In Fig. 8 the results of all observations have been combined to show, as if in a single complete year, the seasonal course of the breeding cycle, the feeding cycle, the content of fat. The two factors named first are represented simply as monthly mean weights, for the course of these two cycles is so regularly repeated that they can be faithfully expressed in this way. But the content of fat has shown some variation from year to year and, therefore, in Fig. 8 the mean content of fat per month, calculated on the data of all years, gives a less satisfactory picture.

In Fig. 8 the breeding cycle is shown as the monthly mean weight of testis and ovary of fish of all sizes combined. The feeding cycle is expressed as the monthly mean weight of food per fish, and the fat cycle as the calculated monthly mean weight of fat present in fish of 19,21 and $24 \mathrm{~cm}$. combined. The data as shown in Fig. 8 are only intended to give a very general picture. 
In Fig. 8 is also shown the seasonal cycle of growth, based on the table on p. I33.

The pilchard's year can be divided into three periods. In the first period, from April to July, feeding becomes vigorous, that is, the intake of material is great. But this is also the time of most active loss of material through spawning which is at its height in these months. As a result, however, of such active feeding, the fish is not only able to ripen its gonads but also to begin active growth and also to begin to replenish its store of fat. The figure shows, however, that the ripening of the gonads takes priority over both growth and fat storage.

The second period in the pilchard's year is from August to October. During this period feeding is less intense, and probably on a plankton poorer in fat than in the spring. But on the other hand, the gonads are quiescent and, therefore, the fish not only continues to grow but continues to lay in reserves of fat. In October feeding becomes brisker and on a plankton probably richer in fat; the gonads meanwhile are making no demands on the resources of the fish. Growth is mainly at an end for the year, and the result is a sudden and rapid accumulation of fat with which the fish can face its winter fast.

The third period of the pilchard's year is from November to March. During this period feeding is at a standstill, and the fish must draw upon its reserves for maintenance. Further, during this period the gonads show a slight but steady enlargement. The result is a heavy decline in the fat content of the fish, and a cessation of growth, which is marked on the scale as a winter ring.

It has been shown (p. II9) that the seasonal variations in the mean weight of a pilchard of given length are due chiefly to the seasonal variations in the weight of fat present, with the 'residue' contributing some part in the larger fish. The water and ash present were shown to play no part in this seasonal variation, being, as it were, the stable framework in which the variable constituents are stored. Therefore the same factors which bring about a seasonal variation in the reserves of fat present in the flesh of the pilchard cause a seasonal variation in the mean weight of a fish of given length.

The degree of exhaustion reached by the end of this period of fast depends on the amount of fat present when it began. In the table below are shown the mean weight of fat, including intestinal fat, present before the winter fast and at the end of the winter fast, in each year of the observations:

$\begin{array}{lrrr}\quad \text { Year } \quad \ldots & 1935-6 & 1936-7 & 1937-8 \\ \text { Wt. of fat before fast } & 18 \cdot 87 & 12 \cdot 06 & 24 \cdot 57 \\ \text { Wt. of fat after fast } & 5 \cdot 76 & \mathrm{I} \cdot 04 & 9 \cdot 43 \\ \text { Loss of fat } & \mathrm{I} \cdot \mathrm{II} & \mathrm{II} \cdot 02 & \mathrm{I} \cdot \mathrm{I} \cdot \mathrm{I} 4\end{array}$

In $1936-7$, when the fast began with a lower fat content, the fat was almost all consumed by the end of the fast, but in 1935-6 and especially in 1936-7 there was a good balance remaining. One can only speculate as to what might 
happen if a year of poor condition, poorer even than that of $1936-7$, were followed by a fasting period in which exceptional demands were made on the fat for maintenance.

In the pilchard of Portugal, as investigated by Ramalho (1933), Wagner \& Ramalho (1936), and Lepierre \& Rodriguez (1938), the course of the seasons is different, in that spawning takes place during the winter, and most intensively in February, March and April. The discrepancy already noted between the fat cycles of the Cornish and Portuguese pilchards is therefore probably due to the difference in time of the spawning cycle in relation to the feeding cycle. The Cornish pilchard tends to show a two-fold replenishment of fat reserves, a lesser one in the early summer, and a greater one in the late autumn, because the income of material due to the heavy feeding on the spring plankton is largely used in the ripening of the gonads, while that due to the autumn feeding can be devoted wholly to the replenishment of the reserves. The Portuguese pilchard, on the other hand, tends to show a single replenishment of fat, reaching a peak in the late summer, because the income of material due to the heavy feeding in the spring is not called upon by the gonads, while that due to the autumn feeding is more than counterbalanced by the demands of the developing gonads, resulting in the beginning of a loss of material at that time of the year in which the Cornish pilchard is at its fattest.

Fig. 8 shows that the breeding cycle and the feeding cycle both reach their peak in the months from April to July. This is contrary to the usual experience with fishes, for most fish are believed to fast during the spawning period. In June I have found pilchards containing at the same time an ovary running with ripe eggs, and a tolerably full stomach. But feeding is clearly a necessity for the pilchard at this time. The winter fast has left no reserves of food material on which to complete the function of the gonads, and the pilchard cannot afford to pass by the richest pasturage of the year, whatever the condition of its gonads.

Another illustration of how the breeding and feeding cycles interact to affect the fat content is furnished by the Sardinellas of Egypt (el Saby, 1937). The main feeding period is in the autumn, when there is a big growth of plankton due to the Nile floods. This period of heavy feeding occurs when the gonads are quiescent, and it results in a sudden and very heavy accumulation of fat, reaching a level as high as 28 or $29 \%$ of the wet weight of the fish by December and January. Spawning occurs during the late spring and early summer, and at this time the fat content may have fallen to less than $3 \%$.

In a recent general account of the seasonal changes in the herring of the North Sea, Lovern \& Wood (I937) show that the fat content of the various races of herrings tends to show two maxima, one in the spring, with its culmination in June to August, and one in the early winter (December). The feeding cycle appears to be the same for all herrings, and is most intensive in May and June, less so in July. This is confirmed by Savage (1935), who, 
further, shows that there is a secondary increase in the intensity of feeding in September.

Those races of herrings which spawn in autumn and winter show their greatest fat content from June to August, and thereafter a rapid loss of fat, for the demands of the gonads are then greater than the income due to feeding. Those races of herrings, however, which spawn in the spring, have their maximum fat content in the autumn, for, as in the pilchard, the spring feeding has been used to nourish the gonads, without leaving much surplus to replenish the reserves of fat.

\section{SUMMARY}

I. In the pilchard (Sardina pilchardus Walbaum) of Cornwall there is a substantial seasonal variation in the mean weight of a fish of given length. The weight is highest in late autumn and early winter, and least at the end of winter and the early spring.

2. These changes in weight are largely due to variations in the fat content of the fish, which are richest in fat at the beginning of the winter fast, and poorest at the end of it. But, especially among the larger fish, the 'residue', chiefly proteins, are drawn upon at the time of the exhaustion of the fat, and consequently at the time of minimum mean weight. The water and ash content show no seasonal variation, and therefore play no part in the observed seasonal variation in the mean weight of the entire fish.

3. The gonads have their lowest mean weight in August, increase in weight slowly throughout the winter, and are at their maximum state of development from April to July. The spawning season, as deduced from these samples, is from March to September.

4. The rate of feeding is greatest in the same months as the spawning months, namely, from April to July. From July to September the average weight of food per stomach decreases, probably not because the planktonic food is then less abundant, but because it is shared among a greater number of fish. In October there is a rally in the rate of feeding, but from November to February or March is a period of fasting, when very little food is taken.

5. The food of the pilchard is exclusively planktonic. In the spring, and again in the autumn, diatoms are abundant or even dominant in the food; in the summer, copepods and crustacea are the chief items of food.

\section{REFERENCES}

BRUCE, J. R., I924. Changes in the chemical composition of the tissues of the herring, etc. Biochem. Fourn., Vol. xvirI.

BygRAve, W., I9II. Report on the plankton of the English Channel in I906. 3rd Report (Southern Area) Mar. Biol. Assoc. Int. Fish. Invest., pp. 235-67.

Clark, F. N., I934. Maturity of the California sardine, etc. Calif. Fish. Bull., No. 42.

Cunningham, J. T., I893. The life history of the pilchard. Fourn. Mar. Biol. Assoc., Vol. III, pp. I48-53.

LE DANors, E., I929. Les races locales de la Sardine des côtes françaises (Manche et Atlantique). Rapp. Proc. Verb. Cons. Int. Explor. Mer, Vol. LIV. 
Desbrosses, P., I933. Étude sur la Sardine de la côte de Bretagne. Rev. Trav. Office Sci. Tech. Pêches Marit., T. vi. Paris.

FAGE, L., 1920. Engraulidae, Clupeidae. Rep. Dan. Oceanogr. Exped. 1908-10, Medit. and Adjacent Seas, Vol. II, Biology A6.

Fisher, R. A., I938. Statistical Methods for Research Workers, 7 th ed. London.

LE GALL, J:, I930. Contribution à l'étude de la Sardine des côtes françaises. Rev. Trav. Office Sci. Tech. Pêches Marit. T. III, Fasc. I. Paris.

— I937. Rapport préliminaire sur les récherches. Sur la biologie de la Sardine. Rapp. Proc. Verb. Cons. Int. Explor. Mer, Vol. crv.

Gough, L., I907. Report on the plankton of the English Channel in 1904-5. 2nd Report (Southern Area) Mar. Biol. Assoc. Int. Fish. Invest.

Hart, J. \& Wailes, H., I932. The food of the pilchard. Rep. Comm. Fish. I931, British Columbia.

Harvey, H. W., Cooper, L. H. N., Lebour, M. V. \& Russell, F. S., I935. Plankton production and its control. Fourn. Mar. Biol. Assoc., Vol. xx.

Hickling, C. F., I938. Notes on the biology of the Cornish pilchard. Rapp. Proc. Verb. Cons. Int. Explor. Mer, Vol. cvir.

- I939. The selective action of the drift-net on the Cornish pilchard. Fourn. Cons. Int. Explor. Mer, Vol. xIv, No. I.

Lepierre \& Rodriguez, E., I938. In Revista de Marinha, No. 35. Lisbon.

Lewis, R. C., I929. The food habits of the California sardine. Bull. Scripps. Inst. Oceanogr., Vol. II, No. 3.

LOVERN, J. \& WOOD, H., I937. Variations in the chemical composition of herring. fourn. Mar. Biol. Assoc., Vol. xxir.

Milroy, T. H., I898. The physical and chemical changes taking place in the ova of certain marine teleosteans. Fisheries, Scotland Sci. Invest. I6th Rep.

Ramalho, A., I933. Fluctuation saisonnière du poids moyen de la Sardine. C.R. Soc. Biol., Paris, T. cxIII, pp. 754-6.

_ 1935. Sur la variation mensuelle du poids moyen de la Sardine. C.R. Soc. Biol., Lisbonne, T. cxx.

RusSell, F. S., I938. On the seasonal abundance of young fish. V. The year 1937. fourn. Mar. Biol. Assoc., Vol. xxII, pp. 493-500.

I939. On the seasonal abundance of young fish. VI. The year 1938. Fourn. Mar. Biol. Assoc., Vol. xxiII, pp. 38I-6.

Savage, R. E., I935. Phytoplankton and the herring. Fish. Invest. Min. Agric. Fish., Series II, Vol. xIV.

eL SABY, M. K., I937. A chemical study of the Egyptian Sardinella. Notes and Memoirs, No. 29. Min. Comm. and Ind., Egypt. Cairo.

Schofield, E. C., I934. Early life history of the Californian sardine. Calif. Fish. Bull., No. 4I.

Swithinbank, H. \& Bullen, G. E., I9I3. The scientific and economic aspects of the Cornish pilchard fishery. I. The food and feeding habits of the pilchard in coastal waters. Mera Publications, No. I. St Albans.

Wagner, D. \& Ramalho, A., I936. Estudos sobre as conserves de Sardinha Portuguesas. Rev. Assoc. Enghen cevis Portu., No. 732. Lisbon.

WIMPENNY, R. S., 1938. A routine method for the estimation of fat in plankton. Fourn. Cons. Int. Explor. Mer, Vol. xiII, No. 3. 